\title{
ON THE ISSUE OF FORMATION OF THE INSTITUTIONAL ENVIRONMENT OF ENVIRONMENTALLY SAFE AGRICULTURAL LAND USE
}

Kupriianchyk I.P, Doctor of Economics.

Email: Kupriyanchik@ukr.net

National University of Life and Environmental Sciences of Ukraine

\begin{abstract}
The article is devoted to the formation of the institutional environment of ecologically safe agricultural land use through the model of harmonization of ecological and economic interests of the subjects of agricultural land use.

The structure of agricultural land use is based on criteria, the content of which represents both economic and environmental interests of society. For example, the landowner (land user) is interested in converting his land into the most economically attractive - arable land, which reflects his private economic interests, and on the other - society is interested in maintaining the optimal state of agricultural landscapes, which in turn provides the optimal ratio of destabilizing, stabilizing and stabilizing reflecting the public environmental interests [7].

Usually such differentiation of interests of subjects of agrarian land use causes situations of impossibility to agree them voluntarily.

Therefore, there is an urgent problem in effective regulatory policy in the field of land use, in particular through the formation of the institutional environment of environmentally safe agricultural land use through the model of harmonization of environmental and economic interests of agricultural land users.

In the article, it is clarified that the institutional model of harmonization of ecological and economic interests of subjects of agrarian land use provides for the introduction of tools to eliminate the conflict of ecological and economic interests, which includes a number of tools, levers and techniques, in particular: -adaptation paradigm; formation of ecological consciousness of land users, ecological morality and ethics; development of the organizational and economic mechanism of formation of ecologically safe agrarian land tenures and land uses optimum through a combination of market and state levers of influence;
\end{abstract}


regulatory and legal support of ecological safety of agricultural land use; optimization of the organizational structure of land use management.

Keywords. Institutional environment, institutions, ecologically safe agricultural land use, land relations, economic development, ecology.

Formulation of the problem. Land decentralization and deregulation of land relations in the course of their implementation affect the components, speed and level of economic growth, the formation of socio-industrial relations, the development of methods of resource use at different levels of government. However, at the same time, there is an urgent need to intensify measures to prevent adverse environmental effects of agricultural land use, which are currently focused primarily on maximizing profits from agricultural activities. After all, the levers of market influence are not able, in the absence of state regulators, to coordinate the work of land users so as to ensure their full compliance with environmental norms and requirements in order to preserve the quality of the environment $[5 ; 10]$. This once again demonstrates the need to improve the institutional tools of regulatory influence on the processes of economic activity of economic entities, which will ensure the effective redistribution of organizational functions in the field of state institutional regulatory activity and its market reflection.

The purpose of the article. To substantiate the institutional model of harmonization of ecological and economic interests of the subjects of agrarian land use.

Presenting main material. Mostly the concept of "institution" is interpreted through the understanding of it as a system of mutually agreed interacting established formal and informal norms and rules that influence management decisions, as well as the functioning of socio-economic entities and their cooperatives [11]. Subjective and object significance of institutions is determined through their theoretical and applied use in the field of institutional spatial analysis, which testifies to the position of individual scholars that the institutions of certain areas, characterized by the existence of subject-object relationships, will have the appropriate meaningful content. Therefore, the generalizing essence of the "institute" can be revealed through the prism of organizational and regulatory activities that affect socio-economic relations. At the same time, institutions are the constraints created by society in order to determine social and economic and political processes. In managerial decision- 
making, the relevant institutions are able to limit the availability and ability of land users to freely use certain types of resources.

Thus, the formation of environmentally friendly agricultural land use is an important tool that through such an institution as environmental restrictions allows for compromise and non-conflict of interests of society, land users and directly agroecosystems (Figure 1).

Taking into account the interests of land users (landowners, land users, society) will not only reduce transaction costs, but also ensure a balanced reproduction of agroecosystems. Therefore, only an effective institutional environment can take into account the interests of all land users through the creation of certain regimes for the use of limited land resources with a sufficient level of regulation.

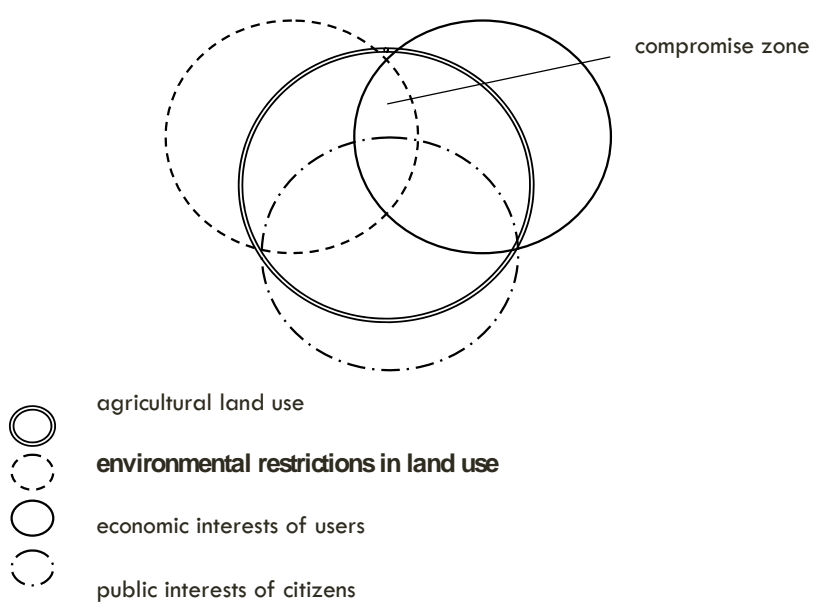

Fig. 1 Areas of formation of interests and compromises in the process of agricultural land use

Source: adapted for [6].

There are many views on the concept of "institutional environment", and the reflection of its essence is often revealed in view of a particular environment or circumstances. In the dictionary, the term "environment" is defined as "matter, bodies that fill a space and have certain properties; sphere". Scientists L. Davis and D. North put certain limitations into the concept of "institutional environment", which ensures the relationship between the conclusion of 
agreements between counterparties [11]. Similar views are shared by a significant number of modern Ukrainian scientists [4;3;9]. They define the institutional environment "as a set of basic imperatives that set limits for determining and establishing land use conditions." In particular, M.A. Khvesyk and VA Golyan defines the institutional environment, "as a set of institutions rules, institutions and organizations and institutional conditions that determine the forms, methods and scale of economic development of water resources and provide for transplantation and convergence of institutions, institutional design and institutional reengineering to address institutional problems" [9, p. 79].

Therefore, we understand the institutional environment of environmentally safe agricultural land use as a set of formal and informal institutions that define and regulate environmental and economic, social and cultural, regulatory, political imperatives of land use in agricultural production, forming a system of regulatory relationships, promoting their implementation .

A feature of the institutional environment is its ability to implement the organizational characteristics of the mechanism of agricultural land management and regulate social and economic, organizational and technological and economic processes with the help of formal and informal institutions. Taking into account the results of the analysis of the above provisions, an institutional model of harmonization of ecological and economic interests of the subjects of agricultural land use has been formed (Fig. 2). This model is based on the interaction of the subjects of agricultural land use in order to overcome contradictions in the implementation of interrelated functions of society and the land user (landowner) in order to meet environmental and economic interests [1, p. 4]. 


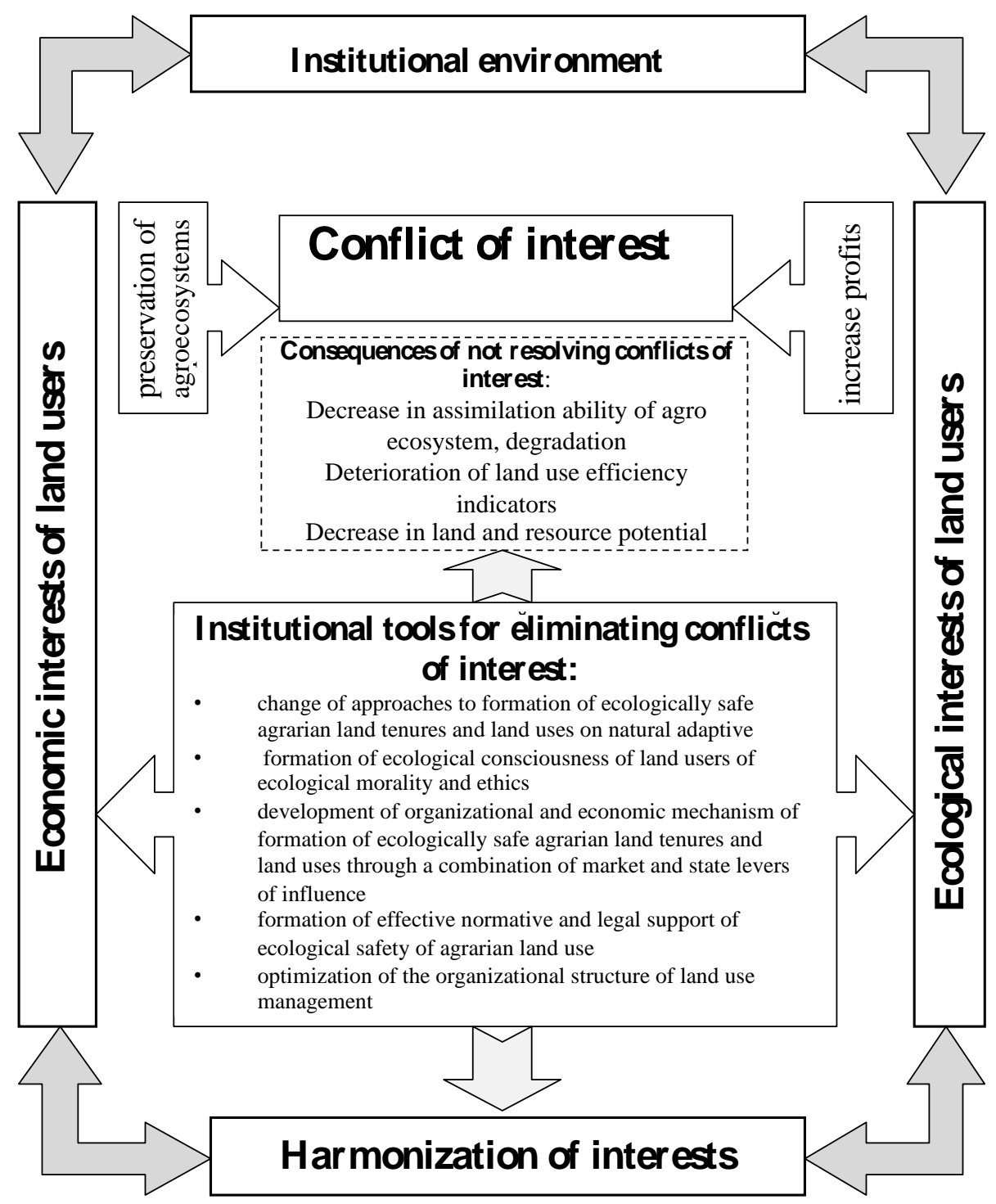

Fig. 2. Institutional model of harmonization of ecological and economic interests of subjects of agrarian land use

Source: formed by the author on the basis of $[6 ; 8]$.

Conclusions. Taking into account the results of the analysis of the above provisions formed. The institutional model of harmonization of ecological and economic interests of subjects of agrarian land use is based on interaction of subjects of agrarian land use for the purpose of overcoming contradictions 
within realization of interconnected functions of a society and the land user (landowner) for the purpose of satisfaction of ecological and economic interests.

The institutional model of harmonization of ecological and economic interests of subjects of agrarian land use provides introduction of tools of liquidation of the conflict of economic and ecological interests, which includes a number of tools, levers and receptions, in particular: formation of ecologically safe agrarian land tenures formation of ecological consciousness of land users, ecological morality and ethics; development of the organizational and economic mechanism of formation of ecologically safe agrarian land tenures and land uses optimum through a combination of market and state levers of influence; regulatory and legal support of ecological safety of agricultural land use; optimization of the organizational structure of land use management.

\section{Reference}

1. Budzyak O. (2015) Kontseptual'ni zasady stratehichnoho rozvytku ekolohobezpechnoho zemlekorystuvannya [ Conceptual principles of strategic development of ecologically safe land use] Ekonomist. no 5. S. 54-56. [in Ukrainian].

2. Kaz'mir P.H., (2009) Orhanizatsiya sil's'kohospodars'koho vykorystannya zemel' na landshaftno-ekolohichniy osnovi [Organization of agricultural land use on a landscape-ecological basis] L'viv. Spolom. [in Ukrainian].

3. Rohach S.M. (2012) Instytutsionalizatsiya ahrarnoho pryrodokorystuvannya [Institutionalization of agrarian nature management], [in Ukrainian].

4. Sayko V.F., Boyko P.I.(2002) Sivozminy u zemlerobstvi Ukrayiny [Crop rotation in agriculture of Ukraine]. Ahrarna nauka, [in Ukrainian].

5. Stupen' M., Kaz'mir L. ( 2014) Instytutsional'ni aspekty ekolohizatsiyi sil's'kohospodars'koho zemlekorystuvannya v Ukrayini [Institutional 
aspects of greening of agricultural land use in Ukraine] Ekonomist. № 5. p. 53-56. [in Ukrainian].

6. Stupen' N.R. (2016)Ekoloho-ekonomichni determinanty efektyvnosti vykorystannya i vidtvorennya zemel'nykh resursiv ahrosfery [Ecological and economic determinants of efficiency of use and reproduction of land resources of agrosphere] Ahrosvit. № 8. p. 61-68 . [in Ukrainian].

7. Stupen' R. (2014) Instytutsiyni umovy zemlevolodinnya ta zemlekorystuvannya u rozvytku ipotechnoho kredytuvannya [ Institutional conditions of land tenure and land use in the development of mortgage lending] Visnyk L'vivs'koho natsional'noho ahrarnoho universytetu. Seriya: Ekonomika APK. № 21(2). p.81-85. [in Ukrainian].

8. Sunduk A.M., Holyan V.A., Androshchuk I.I., Savchuk V.V. (2018) Ahrarne pryrodokorystuvannya v Ukrayini: instytutsional'ne pidhruntya, osnovni tendentsiyi ta finansovo-ekonomichni mekhanizmy ratsionalizatsiyi [ Agrarian nature management in Ukraine: institutional basis, main trends and financial and economic mechanisms of rationalization]. Ekonomika ta derzhava. № 9. p.19-29 [in Ukrainian].

9. Khvesyk M.A. Holyan V.A. (2007)Instytutsional'na model' pryrodokorystuvannya $\mathrm{v}$ umovakh hlobal'nykh vyklykiv [Institutional model of nature management in the context of global challenges ],Kiev. [in Ukrainian].

10.Davis L., North D. (1971) Institutional Change and American Economic Growth, Cambridge: Cambridge University Press

11. Knight J. (1992) Institutions and Social Conflict. Cambridg University Press. 


\section{Купріянчик І.П.}

Анотація. Стаття присвячена питанням формування інституціонального середовища екологобезпечного аграрного землекористування через модель гармонізації екологічних і економічних інтересів суб’єктів аграрного землекористування.

Структура аграрного землекористування побудована на критеріях, у змісті яких представлені як економічні, так і екологічні інтереси суспільства. Наприклад, землевласник (землекористувач) зацікавлений в переведенні своїх земельних угідь у найбільш економічно привабливі ріллю, що відображає його приватні економічні інтереси, а з іншого суспільство зацікавлене у підтриманні оптимального стану агроландшафтів, який своєю чергою забезпечується оптимальним співвідношенням дестабілізуючих та стабілізуючих сільськогосподарських угідь, що відображає суспільні екологічні інтереси [7].

Зазвичай така диференціація інтересів суб'єктів аграрного землекористування зумовлює ситуації неможливості добровільно їх узгодити.

Тож виникає нагальна проблема у ефективній регуляторній політиці у сфері землекористування, зокрема i шляхом формування інституціонального середовища екологобезпечного аграрного землекористування через модель гармонізації екологічних і економічних інтересів суб'єктів аграрного землекористування.

У статті, 3'ясовано, що інституціональна модель гармонізації екологічних i економічних інтересів суб’єктів аграрного землекористування передбачає запровадження інструментарію ліквідації конфлікту екологічних й економічних інтересів, що налічує низку 
інструментів, важелів та прийомів, зокрема: формування екологобезпечних аграрних землеволодінь і землекористувань на засадах природно-адаптаційної парадигми; формування екологічної свідомості землекористувачів, екологічної моралі та етики; розвиток організаційноекономічного механізму формування екологобезпечних аграрних землеволодінь i землекористувань оптимальному через поєднання ринкових та державних важелів впливу; нормативно-правове забезпечення екологічної безпеки аграрного землекористування; оптимізація організаційної структури управління землекористуванням.

Ключові слова. Інституціональне середовище, інституції, екологобезпечне аграрне землекористування, земельні відносини, економічний розвиток, екологія.

\section{Куприянчик И.П.}

\section{К ВОПРОСУ ФОРМИРОВАНИЯ ИНСТИТУЦИОНАЛЬНОЙ СРЕДЫ ЭКОЛОГОБЕЗОПАСНОГО АГРАРНОГО ЗЕМЛЕПОЛЬЗОВАНИЯ}

Аннотация. Статья посвящена вопросам формирования институциональной среды экологобезопасного аграрного землепользования используя модель гармонизации экологических и экономических интересов субъектов аграрного землепользования.

Структура аграрного землепользования построена на условиях, в содержании которых представлены как экономические, так и экологические интересы общества. Например, землевладелец (землепользователь) заинтересован в переводе своих земельных угодий в наиболее экономически привлекательные - пашню, отражающий его частные экономические интересы, а с другой - общество заинтересовано в поддержании оптимального состояния агроландшафтов, который в свою 
очередь обеспечивается оптимальным соотношением дестабилизирующих и стабилизирующих сельскохозяйственных угодий, что отражает общественные экологические интересы [7].

Обычно такая дифференциация интересов субъектов аграрного землепользования приводит ситуации невозможности добровольно их согласовать.

Поэтому возникает насущная проблема в эффективной регуляторной политике в сфере землепользования, в том числе путем формирования институциональной среды экологобезопасного аграрного землепользования через модель гармонизации экологических и экономических интересов субъектов аграрного землепользования.

В статье, установлено, что институциональная модель гармонизации экологических и экономических интересов субъектов аграрного землепользования предусматривает введение инструментария ликвидации конфликта экологических и экономических интересов, насчитывает ряд инструментов, рычагов и приемов, в частности: формирование экологобезопасных аграрных землевладений и землепользовании на основе естественно -адаптацийнои парадигмы; формирование экологического сознания землепользователей, экологической морали и этики; развитие организационно-экономического механизма формирования экологобезопасных аграрных землевладений и землепользовании оптимальном через сочетание рыночных и государственных рычагов воздействия; нормативно-правовое обеспечение экологической безопасности аграрного землепользования; оптимизация организационной структуры управления землепользованием. 
Ключевые слова. Институциональная среда, институты, экологобезопасное аграрное землепользование, земельные отношения, экономическое развитие, экология. 